\title{
HIGH LEVELS OF INTERFERON ALPHA IN THE SERA OF CHILDREN WITH DENGUE VIRUS INFECTION
}

\author{
ICHIRO KURANE, BRUCE L. INNIS, SUCHITRA NIMMANNITYA, ANANDA \\ NISALAK, ANTHONY MEAGER, AND FRANCIS A. ENNIS \\ Division of Infectious Diseases and Immunology, Department of Medicine, University of \\ Massachusetts Medical Center, Worcester, Massachusetts; Department of Virology, Armed Forces \\ Research Institute of Medical Sciences, Bangkok 10400, Thailand; Children's Hospital, Bangkok, \\ 10400 Thailand; Division of Immunobiology, National Institute for Biological Standard and \\ Control, Hertfordshire, United Kingdom
}

\begin{abstract}
We measured the levels of interferon alpha (IFN $\alpha$ ) in the sera of Thai children hospitalized with dengue hemorrhagic fever (DHF) or dengue fever (DF) to examine the role of IFN $\alpha$ in dengue virus infections of humans. The percentage of patients who had detectable levels of IFN $\alpha(\geq 3 \mathrm{U} / \mathrm{ml})$ was higher in patients with DHF $(80 \%, P<0.001)$ and in patients with DF $(60 \%, P<0.001)$ than in healthy Thai children $(7 \%)$. The levels of IFN $\alpha$ were higher in patients with DHF and in patients with DF on the first few days after the onset of fever than in healthy Thai children. The average levels of IFN $\alpha$ in patients with DHF were high two days before defervescence, decreasing gradually until the day of defervescence. There was a subset of patients with DHF who had increasing levels of IFN $\alpha$ after defervescence. However, the levels of IFN $\alpha$ in patients with DF were not high after fever subsided. The levels of IFN $\alpha$ were not different among children with DHF grades 1 , 2 and 3. Among patients with DHF, $T$ lymphocytes were activated to a higher degree in high IFN $\alpha$ producers than in low IFN $\alpha$ producers. These results indicate that similarly high levels of IFN $\alpha$ are produced in vivo during the acute stages of DHF and DF, and that high levels of IFN $\alpha$ remain after fever subsides in some patients with DHF, but not in patients with DF.
\end{abstract}

Dengue virus infections are a major cause of morbidity in tropical and subtropical areas of the world. Dengue virus infection causes two forms of illness; dengue fever (DF) and dengue hemorrhagic fever (DHF). ${ }^{1}$ Dengue fever is a selflimited febrile disease, while DHF is a severe, sometimes fatal syndrome characterized by hemorrhagic manifestations and plasma leakage that may lead to shock. The mechanisms of recovery from dengue virus infection and the pathogenesis of DHF are not clearly understood.

We have reported that dengue virus-infected cells are lysed by natural killer cells and by antibody-dependent cell-mediated cytotoxicity. ${ }^{2} \mathrm{We}$ have also reported the presence of dengue virusspecific, cytotoxic $\mathrm{T}$ lymphocytes that lyse dengue virus-infected cells in a major histocompatibility complex-restricted fashion. ${ }^{3,4}$ Antibodies to dengue viruses neutralize the virus and can prevent infection. ${ }^{5}$ These immune responses may be important in prevention and recovery from dengue virus infection, and may contribute to the pathogenesis of DHF. We have detected higher levels of activation of $\mathrm{T}$ lymphocytes in patients with DHF than in those with DF, and have hypothesized that dengue virus-specific $T$ cells play an important role in the pathogenesis of DHF. ${ }^{6}$ Another host defense mechanism that should be considered is interferon (IFN) production. It has been reported that IFN has an important role in controlling viral infections. ${ }^{7}$ We have reported that dengue virus-infected monocytes produce IFN $\alpha,{ }^{8}$ and that dengue virus-infected monocytes also induced IFN $\alpha$ from autologous nonimmune lymphocytes. ${ }^{9}$ Interferon alpha produced by these two mechanisms protects uninfected monocytes from dengue virus infection.8, 9 In addition to antiviral effects, IFN $\alpha$ has immunoregulating effects on natural killer cells, ${ }^{10} \mathrm{~T}$ cells, ${ }^{11}$ and B cells. ${ }^{12}$ Thus, IFN $\alpha$ may have important regulatory roles in the pathogenesis of DHF.

In this study, we examined the levels of IFN $\alpha$ in the sera of patients hospitalized with DHF and those hospitalized with DF, and compared those data with levels of IFN $\alpha$ in the sera of healthy Thai children. The results show that significantly higher levels of IFN $\alpha$ are detected in 
the sera of patients with DHF or DF before and on the day of defervescence than in the sera of healthy Thai children. The average levels of IFN $\alpha$ are still high 7-19 days after defervescence in some patients with DHF, while the levels are not high after fever subsides in patients with DF.

\section{PATIENTS AND METHODS}

\section{Patients and normal control donors}

We examined serial serum specimens from 45 children with an age range of 5-14 years (35 children with DHF and 10 children with DF) who were hospitalized with dengue virus infections during 1987 and 1988 in the hemorrhagic fever unit of the Bangkok Children's Hospital. These sera were obtained from a randomly selected group of sequential patients whose sera were submitted for evaluation of suspected dengue virus infection. Specimens were collected for diagnostic studies by nurses participating in the project within $24 \mathrm{hr}$ of admission to the hospital and daily until discharge; a convalescent specimen was also collected from each child 7-10 days after hospital admission. A portion of each specimen was kept at $-70^{\circ} \mathrm{C}$ and was available for analysis.

To study healthy children (controls), we examined aliquots of single serum specimens from a random sample of healthy Thai children $(n=$ 30 , age range 6-11 years) obtained in an earlier cross-sectional study of hepatitis antibody prevalence. These sera were stored at $-70^{\circ} \mathrm{C}$ from the time of collection until assay.

A diagnosis of dengue hemorrhagic fever was assigned to children with dengue infection when the level of thrombocytopenia and signs of hemorrhage and plasma leakage met established criteria. ${ }^{13}$ Hospitalized patients were followed with frequent determinations of blood pressure and pulse. Measurements of hematocrit in blood obtained by fingerprick were recorded at 3-4-hr intervals, according to vital signs. Physical findings of plasma leakage (pleural effusion, ascites) and indications of circulatory collapse (cyanosis, cold extremities) were recorded in the clinical record. Whenever feasible, chest radiographs including decubitus views were performed to document the presence of pleural fluid. Hemorrhagic manifestations (positive tourniquet test result for capillary fragility, skin hemorrhages, epistaxis, and gingival, gastrointestinal, or urinary tract hemorrhage) were also recorded. Without knowl- edge of IFN $\alpha$ levels, three of the investigators (S. N., B. L. I., and A. N.) reviewed every record, including radiographs, to assign a diagnosis. Cases of dengue infection that did not meet the World Health Organization (WHO) definition of DHF ${ }^{13}$ were classified as dengue fever $(n=10)$. The severity of cases of DHF was categorized according to the WHO grading scheme: ${ }^{13}$ grade 1 $=$ fever accompanied by nonspecific constitutional symptoms (the only hemorrhagic manifestation is a positive tourniquet test result); grade 2 = spontaneous bleeding, in addition to the manifestations of grade 1 patients, usually in the form of skin and/or other hemorrhages; grade 3 $=$ circulatory failure manifested by rapid and weak pulse, narrowing of pulse pressure $(\leq 20$ $\mathrm{mm} \mathrm{Hg}$ ) or hypotension, with the presence of cold, clammy skin and restlessness.

Dengue virus infections were confirmed by the detection of antiviral IgM or increasing titers of antiviral hemagglutination-inhibiting antibodies or by virus isolation from plasma, according to previously published methods. ${ }^{14}$ Cases of dengue infection were categorized as secondary (dengue infection in a child previously infected with a heterologous flavivirus) or primary (no prior flavivirus infection) according to the presence or absence of an anamnestic antiflavivirus antibody response. ${ }^{14}$. Table 1 shows the age and sex distribution and serologic data of patients and control subjects.

\section{Assay for IFNa}

The levels of IFN $\alpha$ were measured in sandwich-type enzyme-linked immunosorbent assays (ELISA) as previously described. ${ }^{15,}{ }^{16}$ Fifty microliters of purified monoclonal antibodies to human IFN $\alpha^{16.17}$ at a concentration of $10 \mu \mathrm{g} / \mathrm{ml}$ was coated on U-bottomed wells of polyvinyl chloride microtiter plates (Dynatech, McLean, VA) for $1 \mathrm{hr}$ at $37^{\circ} \mathrm{C}$. The remaining sites in the wells were blocked overnight with $150 \mu$ l of blocking buffer ( $2 \%$ bovine serum albuminphosphate-buffered saline [PBS]) at $4^{\circ} \mathrm{C}$. Excess antibodies and blocking buffer were removed and the wells were washed four times with $0.05 \%$ Tween 20-PBS. Following the last wash, serial dilutions of human IFN $\alpha$ standard (first international reference preparation for human leukocyte interferon, $69 / 19,5,000$ IU/ampule) or serum samples were added (50 $\mathrm{\mu l} /$ well) and incubated at $37^{\circ} \mathrm{C}$ for $1 \mathrm{hr}$. The wells were then 
TABLE 1

Age and sex distribution and dengue antibody responses of the patients and control subjects*

\begin{tabular}{|c|c|c|c|c|c|c|}
\hline \multirow[b]{2}{*}{ Subjects } & \multirow[b]{2}{*}{ No. } & \multicolumn{2}{|c|}{ Sex } & \multirow{2}{*}{$\begin{array}{c}\text { Average } \pm \text { SD, years } \\
\text { (range) }\end{array}$} & \multicolumn{2}{|c|}{ Dengue serology } \\
\hline & & Male & Female & & Primary & Secondary \\
\hline DHF & 35 & 19 & 16 & $9.1 \pm 2.9(5-14)$ & 3 & 32 \\
\hline & 10 & 6 & 4 & $9.9 \pm 2.9(5-14)$ & 4 & 6 \\
\hline Healthy children & 30 & 13 & 17 & $7.9 \pm 1.4(6-11)$ & 0 & 0 \\
\hline
\end{tabular}

- DHF = dengue hemorrhagic fever, DF = dengue fever.

washed four times with Tween 20-PBS. Horseradish peroxidase-linked calf antihuman IFN $\alpha$ immunoglobulin at a 1:4,000 dilution in $10 \%$ fetal calf serum-PBS $(50 \mu 1 /$ well) was added and incubated for $30 \mathrm{~min}$ at $37^{\circ} \mathrm{C}$. Finally, the wells were washed three times with Tween 20-PBS and twice with $0.1 \mathrm{M}$ citrate phosphate buffer, $\mathrm{pH}$ 5.0 , followed by the addition of $o$-phenylenediamine substrate at a concentration of $1 \mathrm{mg} / \mathrm{ml}$ in $0.1 \mathrm{M}$ citrate phosphate buffer containing $0.006 \%$ hydrogen peroxide. Color was developed in the dark for $\mathbf{3 0} \mathrm{min}$ at room temperature and the reaction was terminated by the addition of $50 \mu \mathrm{l}$ of $1 \mathrm{M} \mathrm{H}_{2} \mathrm{SO}_{4}$ to each well. Optical densities were read at $492 \mathrm{~nm}$ in a Titertek Multiskan plate reader (Flow Laboratories, McLean, VA). The levels of IFN $\alpha$ in serum samples were interpolated from the IFN $\alpha$ standard calibration curve, using the 1 st international reference preparation for human leukocyte interferon, 69/19, 5,000 IU/ ampule. The detection limit of the assay was 3 $\mathrm{IU} / \mathrm{ml}$.

Assays for soluble interleukin-2 receptor (sIL-2R) and soluble antigens of CD4 and CD8 cells (sCD4 and $S C D 8$ )

The levels of sIL-2R, SCD4, and SCD8 were measured using commercial ELISAs (cell-free IL-2 receptor test kit, cell-free CD4 test kit, and cell-free T8 test kit, respectively; T Cell Sciences, Inc., Cambridge, MA). The results are expressed as units per milliliter based on the standard provided by the manufacturer.

\section{Assay for $I L-2$}

The levels of IL-2 were measured using a commercial ELISA (Intertest-2; Genzyme, Boston, MA). The results are expressed as units per milliliter.

\section{Assay for IFNy}

Levels of IFN $\gamma$ were determined because they are one of the markers that reflect $\mathrm{T}$ cell activation in patients with DHF. They were measured using a commercial radioimmunoassay (Centocor Diagnostics, Malvern, PA). The results are expressed as international units per milliliter.

\section{Statistical analysis}

Differences between values were examined using the Student's $t$-test and the chi-square test. The levels of IFN $\alpha$ were log-transformed for statistical analysis. Undetectable levels of IFN $\alpha(<$ $3 \mathrm{IU} / \mathrm{ml}$ ) were considered to be $1 \mathrm{IU} / \mathrm{ml}$ for logtransformation. Differences yielding $P$ values of $\leq 0.05$ were regarded as significant.

\section{RESULTS}

Levels of IFNa in the sera of patients with $D H F$ or $D F$

The sera from patients with DHF or DF were examined for levels of IFN $\alpha$. These levels were then compared with levels in the sera of healthy Thai children. The day of onset of fever was defined as day 0 (Figure 1). Interferon alpha was detected in $80 \%$ ( 28 of 35 ) of the patients with DHF and in $60 \%$ (6 of 10$)$ of the patients with DF during days 1-20 after the onset of fever, while only $7 \%$ ( 2 of 30 ) of the sera of healthy Thai children contained detectable levels of IFN $\alpha$ $(P<0.001$ for DHF and $P<0.001$ for DF, by chi-square test) (Figure 1).

The levels of IFN $\alpha$ in the sera of patients with acute DHF were higher than those in the sera of healthy Thai children $(P<0.001$ on day 3 and $P<0.05$ on days 2 and 4 ), and the levels were also high on days 6-20 after onset of fever $(P<$ 0.05 on days $6, P<0.02$ on day 7 , and $P<$ 


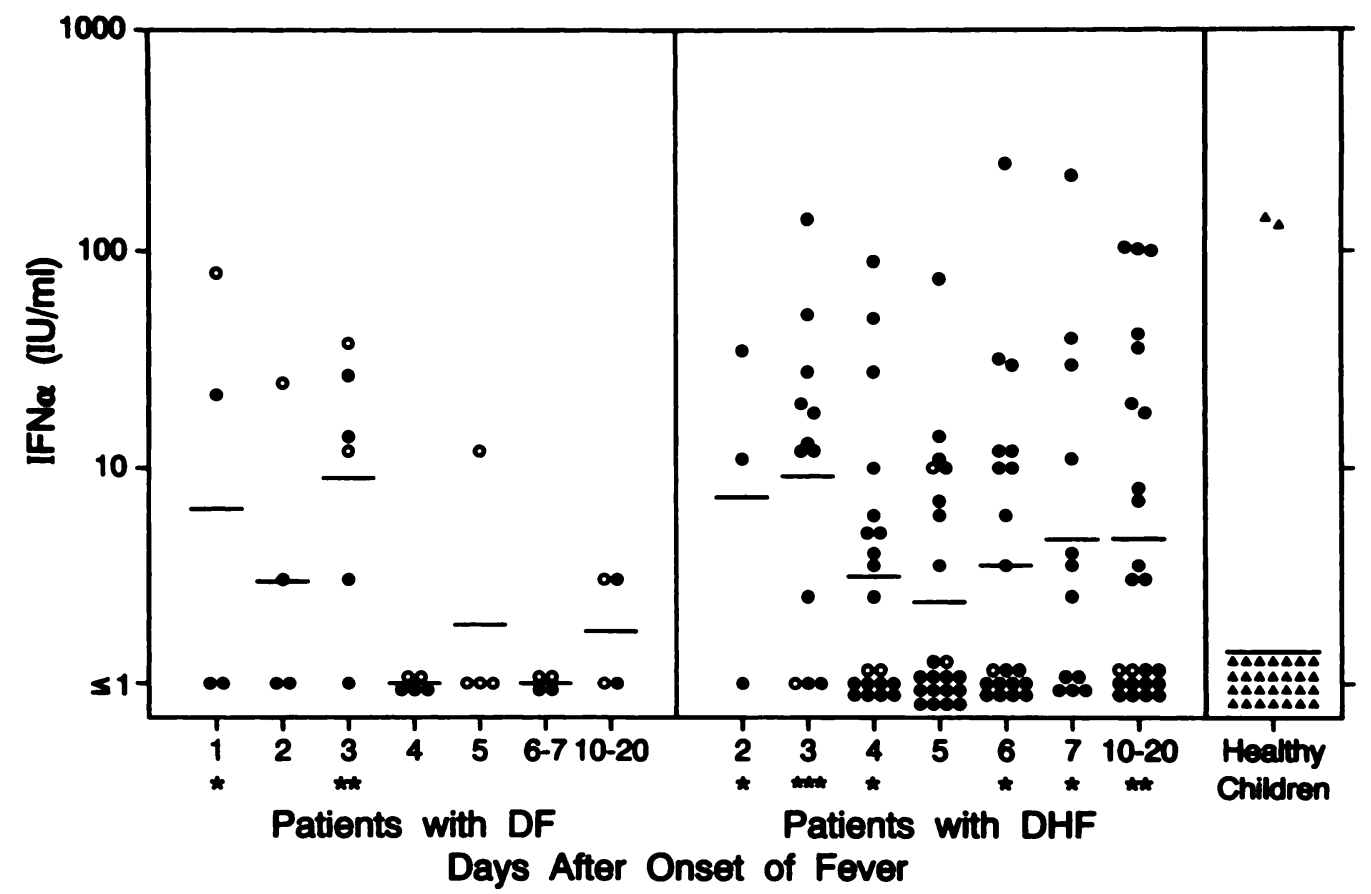

FIGURE 1. Levels of interferon alpha (IFN $\alpha$ ) in the sera of patients with dengue hemorrhagic fever (DHF) and those with dengue fever (DF) on days after the onset of fever. The geometric mean titers (bars) of IFN $\alpha$ were $1.39 \mathrm{IU} / \mathrm{ml}(\mathrm{n}=30)$ in healthy Thai children, $7.28 \mathrm{IU} / \mathrm{ml}(\mathrm{n}=3)$ on day $2,9.14 \mathrm{IU} / \mathrm{ml}(\mathrm{n}=12)$ on day $3,3.10 \mathrm{IU} / \mathrm{ml}(\mathrm{n}=20)$ on day $4,2.37 \mathrm{IU} / \mathrm{ml}(\mathrm{n}=22)$ on day $5,3.49 \mathrm{IU} / \mathrm{ml}(\mathrm{n}=20)$ on day $6,4.65 \mathrm{IU} / \mathrm{ml}(\mathrm{n}$ $=12)$ on day 7 , and $4.68 \mathrm{IU} / \mathrm{ml}(\mathrm{n}=25)$ on days $10-20$ in the sera of patients with DHF, and $6.47 \mathrm{IU} / \mathrm{ml}(\mathrm{n}$ $=4)$ on day $1,2.94 \mathrm{IU} / \mathrm{ml}(\mathrm{n}=4)$ on day $2,8.95 \mathrm{IU} / \mathrm{ml}(\mathrm{n}=6)$ on day $3, \leq 1 \mathrm{IU} / \mathrm{ml}(\mathrm{n}=5)$ on day $4,1.86$ $\mathrm{IU} / \mathrm{ml}(\mathrm{n}=4)$ on day $5, \leq 1 \mathrm{IU} / \mathrm{ml}(\mathrm{n}=4)$ on days $6-7$, and $1.73 \mathrm{IU} / \mathrm{ml}(\mathrm{n}=4)$ on days $10-20$ in the sera of patients with DF. $\circ=$ primary, hospitalized; $\bullet=$ secondary, hospitalized; $\Delta=$ healthy Thai children. Levels of IFN $\alpha$ were compared with the levels in the healthy Thai children by Student's $t$-test after log-transformation. $* P<0.05 ; * P<0.01 ; * * P<0.001$.

0.005 on days 10-20). The levels of IFN $\alpha$ in the sera of patients with acute DF were higher than those in the sera of healthy Thai children $(P<$ 0.05 on day 1 and $P<0.005$ on day 3 ); however, the levels were not high on days 4-20 after onset of fever (Figure 1).

Levels of IFNa in the sera of patients before and after the day of defervescence

The timing of plasma leakage in patients with DHF is predictable; circulatory collapse occurs as fever subsides. Therefore, we evaluated the levels of IFN $\alpha$ in the patients with DHF or DF, defining the day of defervescence as day 0 (Figure 2). The average levels of IFN $\alpha$ in patients with DHF were highest two days before defervescence, and decreased gradually until the day of defervescence. However, the average levels of
IFN $\alpha$ did not change during days $0-19$. The levels of IFN $\alpha$ in patients with DF were high one day before and on the day of defervescence, but these levels were not high after the fever subsided.

Changes in the serum levels of IFNa in each patient with $D H F$

We attempted to determine the changes in the levels of IFN $\alpha$ in each patient during the course of DHF. Patients with DHF were separated into two groups, based on the levels of IFN $\alpha$ on days 7-12 after defervescence: 11 subjects who had detectable levels of IFN $\alpha$ ( $>3 \mathrm{IU} / \mathrm{ml}$ ) (Figure 3A) and 10 patients who did not have detectable levels of IFN $\alpha$ (Figure 3B). Most of the patients who had detectable levels of IFN $\alpha$ on days 7-12 after defervescence had lower levels of IFN $\alpha$ dur- 


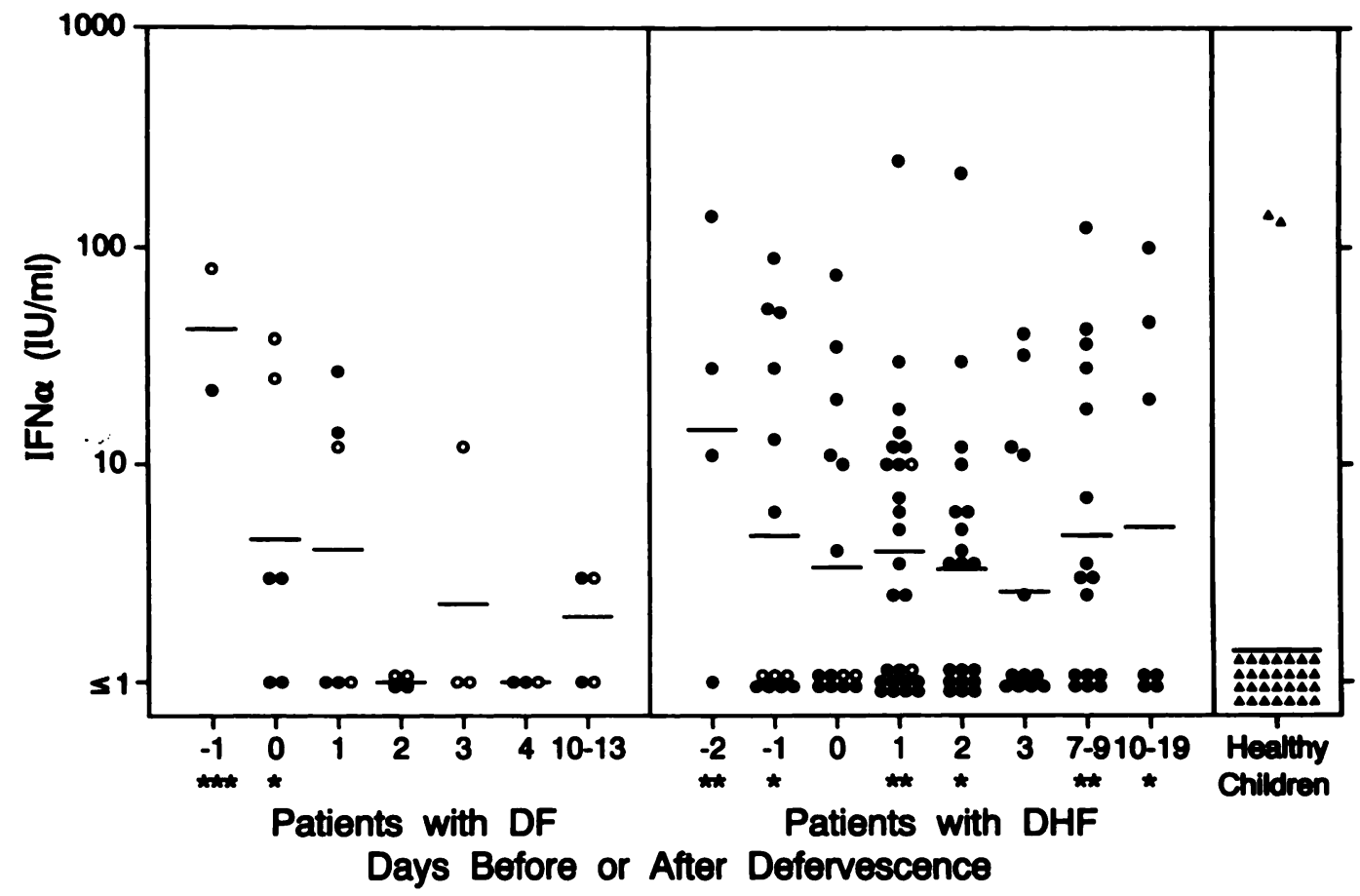

FIGURE 2. Levels of interferon alpha (IFN $\alpha$ ) in the sera of patients with dengue hemorrhagic fever (DHF) and those with dengue fever (DF) on days before or after defervescence. The day of defervescence is defined as day 0 . The geometric mean titers (bars) of IFN $\alpha$ were $1.39 \mathrm{IU} / \mathrm{ml}(\mathrm{n}=30)$ in healthy Thai children, $14.4 \mathrm{IU} /$ $\mathrm{ml}(\mathrm{n}=2)$ on day $-2,4.68 \mathrm{IU} / \mathrm{ml}(\mathrm{n}=13)$ on day $-1,3.36 \mathrm{IU} / \mathrm{ml}(\mathrm{n}=14)$ on day $0,3.97 \mathrm{IU} / \mathrm{ml}(\mathrm{n}=27)$ on day $1,3.30 \mathrm{IU} / \mathrm{ml}(\mathrm{n}=20)$ on day $2,2.59 \mathrm{IU} / \mathrm{ml}(\mathrm{n}=11)$ on day $3,4.68 \mathrm{IU} / \mathrm{ml}(\mathrm{n}=16)$ on days $7-9$, and $5.11 \mathrm{IU} / \mathrm{ml}(\mathrm{n}=7)$ on days $10-19$ in the sera of patients with $\mathrm{DHF}$, and $41.9 \mathrm{IU} / \mathrm{ml}(\mathrm{n}=2)$ on day $-1,4.52$ $\mathrm{IU} / \mathrm{ml}(\mathrm{n}=6)$ on day $0,4.07 \mathrm{IU} / \mathrm{ml}(\mathrm{n}=6)$ on day $1, \leq 1 \mathrm{IU} / \mathrm{ml}(\mathrm{n}=4)$ on day $2,2.29 \mathrm{IU} / \mathrm{ml}(\mathrm{n}=3)$ on day $3, \leq 1 \mathrm{IU} / \mathrm{ml}(\mathrm{n}=3)$ on day 4 , and $1.73 \mathrm{IU} / \mathrm{ml}(\mathrm{n}=4)$ on days $10-13$ in the sera of the patients with DF. $0=$ primary, hospitalized; $\bullet=$ secondary, hospitalized; $\Delta=$ healthy Thai children. Levels of IFN $\alpha$ were compared with the levels in the healthy Thai children by Student's $t$-test after log-transformation. ${ }^{*} P<0.05 ;{ }^{* *} P<0.01$; $* * * P<0.001$.

ing days 0-4 after defervescence (Figure 3A). Most of the patients who did not have detectable levels of IFN $\alpha$ during days 7-12 had detectable levels of IFN $\alpha$ during days $0-4$ after defervescence (Figure 3B). It is of interest that high levels of IFN $\alpha$ were detected on days 7-19 after defervescence in some patients who had lower levels of IFN $\alpha$ during the early stages of illness.

Comparison of the levels of IFN $\alpha$ among patients with $D H F$ grades 1,2 , and 3

The levels of IFN $\alpha$ were compared among patients with DHF grades 1, 2, and 3 from one day before defervescence to nine days after defervescence (Figure 4). They did not differ among these three groups.
Levels of $T$ cell activation in high IFNa producers and low IFNa producers among patients with $D H F$

We have previously reported that $\mathrm{T}$ lymphocytes are highly activated in patients with DHF by determining the high serum levels of sIL-2R, sCD4, sCD8, IL-2, and IFN $\gamma \cdot{ }^{6}$ The levels of these soluble cell-surface proteins and lymphokines were compared between high IFN $\alpha$ producers and low IFN $\alpha$ producers among patients with DHF during days 2-8 after onset of fever (Table 2). Patients who had serum IFN $\alpha$ levels higher than $30 \mathrm{IU} / \mathrm{ml}$ at least one day during days $2-8$ after onset of fever were defined as high IFN $\alpha$ producers. Patients who did not have serum IFN levels higher than $10 \mathrm{IU} / \mathrm{ml}$ during this period were defined as low IFN $\alpha$ producers. The levels 
of sIL-2R were significantly higher in high IFN $\alpha$ producers than in low IFN $\alpha$ producers $(P<$ 0.001 ). The levels of SCD4, IL-2, and IFN $\gamma$ were higher in high IFN $\alpha$ producers than in low IFN $\alpha$ producers, but the differences were not statistically significant. These results suggest that $T$ lymphocytes are activated to a higher degree in high IFN $\alpha$ producers than in low IFN $\alpha$ producers.

\section{DISCUSSION}

In this study, we examined the levels of IFN $\alpha$ in the sera of patients hospitalized with DHF or DF. The percentage of subjects who had detectable levels of IFN $\alpha$ and the levels of IFN $\alpha$ on days 1-3 after the onset of fever were higher in patients with DHF or DF than in healthy Thai children. These results indicate that high levels of IFN $\alpha$ are produced in vivo during the acute stage of dengue virus infection.

The average levels of IFN $\alpha$ in the sera of patients with DHF were also high on days 4-20 after the onset of fever, while the levels of IFN $\alpha$ in the sera of patients with DF were not high after day 4. The levels of IFN $\alpha$ in patients with DHF were high two days before defervescence and decreased gradually until the day of defervescence, defined as day 0 . The average levels of IFN $\alpha$ did not change between days 0 and 19 . Approximately half of the patients with DHF had detectable levels of IFN $\alpha$ on days 7-19 after defervescence, and the levels of IFN $\alpha$ were higher on days $7-19$ than on days $0-4$ after defervescence in these patients. In contrast, the average levels of IFN $\alpha$ in patients with DF were high one day before defervescence and on the
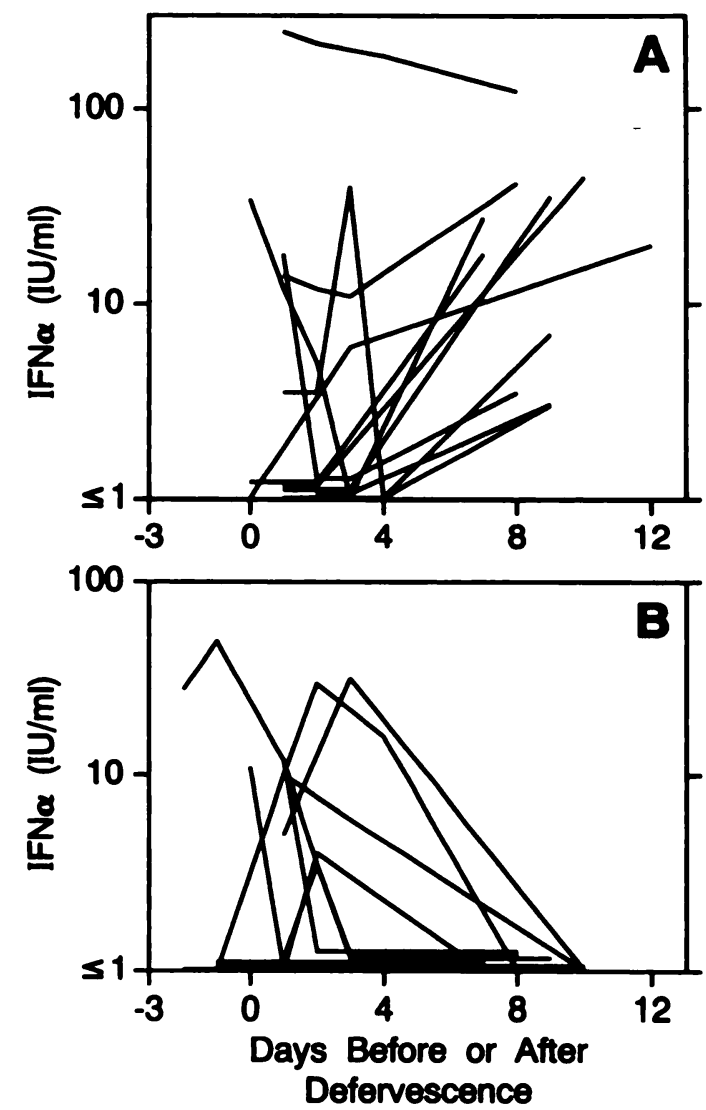

FIGURE 3. Changes in the levels of interferon alpha (IFN $\alpha$ ) in each patient with dengue hemorrhagic fever during the course of illness. Each line represents the changes in the levels of IFN $\alpha$ in one patient. A, patients who had detectable levels of IFN $\alpha(\geq 3 \mathrm{IU} / \mathrm{ml})$ in their sera on days 7-12 after defervescence. $B$, patients who did not have detectable levels of IFN $\alpha$ on days 7-12 after defervescence.

TABLE 2

Levels of soluble cell-surface proteins and lymphokines in high interferon alpha (IFN $\alpha$ ) producers and low IFNa producers among the patients with dengue hemorrhagic fever $(D H F)^{*}$

\begin{tabular}{|c|c|c|c|c|c|}
\hline \multirow[b]{2}{*}{ Markers } & \multicolumn{2}{|c|}{$\begin{array}{l}\text { High IFN } \alpha \text { producers } \\
(>30 \mathrm{IU} / \mathrm{ml})\end{array}$} & \multicolumn{2}{|c|}{$\begin{array}{l}\text { Low IFN } \alpha \text { producers } \\
(<10 \mathrm{IU} / \mathrm{ml})\end{array}$} & \multirow[b]{2}{*}{$\mathbf{P}$} \\
\hline & $\begin{array}{l}\text { Titers, U/ml } \\
\text { (mean } \pm \text { SD) }\end{array}$ & $\begin{array}{c}\text { No. of } \\
\text { samples }\end{array}$ & $\begin{array}{l}\text { Titers, U/ml } \\
\text { (mean } \pm \text { SD) }\end{array}$ & $\begin{array}{l}\text { No. of } \\
\text { samples }\end{array}$ & \\
\hline sIL-2R & $5,921 \pm 781$ & 4 & $2,079 \pm 261$ & 7 & $<0.001$ \\
\hline sCD4 & $48.4 \pm 9.5$ & 5 & $31.2 \pm 3.0$ & 9 & $<0.1 t$ \\
\hline sCD8 & $1,270 \pm 225$ & 7 & $1,355 \pm 164$ & 9 & $<0.8 \dagger$ \\
\hline IL-2 $\left(\log _{10}\right)$ & $1.654 \pm 0.372$ & 7 & $1.391 \pm 0.272$ & 9 & $<0.8 \dagger$ \\
\hline IFN $\gamma\left(\log _{10}\right)$ & $0.200 \pm 0.244$ & 7 & $-0.201 \pm 0.186$ & 9 & $<0.5 t$ \\
\hline
\end{tabular}

* Patients with DHF who had serum IFN $\alpha$ levels higher than $30 \mathrm{IU} / \mathrm{ml}$ at least one day during days 2-8 after the onset of fever were defined as high IFNa producers. Patients with DHF who did not have serum IFN $\alpha$ levels higher than 10 IU/ml during days $2-8$ were defined as low IFNa responders. The highest levels of soluble interleukin-2 receptor (sIL-2R), sCD4, sCD8, IL-2, and IFNr during days 2-8 afler the onset of fever were compared between high IFN $\alpha$ producers and low IFN $\alpha$ producers by Student's $t$-test. The titers of IL-2 and IFN $\gamma$ were log-transformed for analysis. $\dagger$ Not significant. 


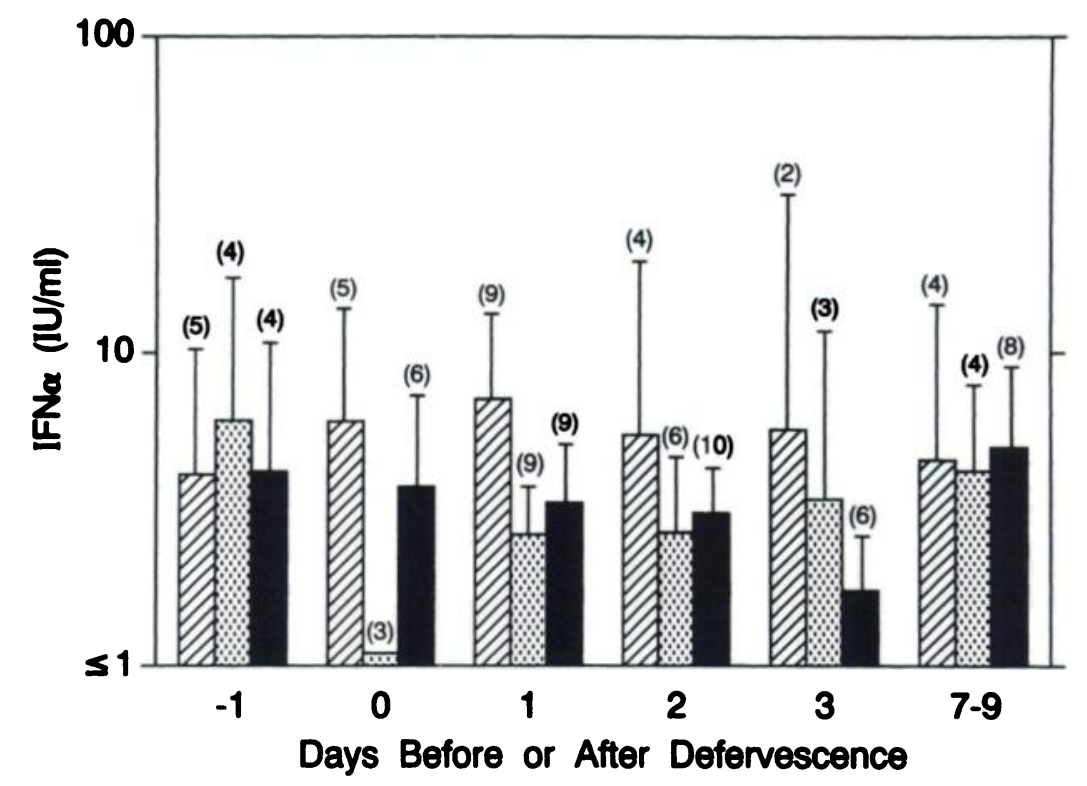

FIGURE 4. Levels of interferon alpha (IFN $\alpha$ ) in patients with dengue hemorrhagic fever grades 1, 2, and 3. Levels are shown as mean titers + SEM. Values in parentheses above the bars are the number of samples. Hatched bars $=$ grade 1 ; dotted bars $=$ grade 2 ; solid bars $=$ grade 3 .

day of defervescence, but decreased after the fever subsided.

The origins of IFN $\alpha$ detected in the sera are not clear. We have reported that dengue virusinfected monocytes produce IFN $\alpha,{ }^{8}$ and that these dengue virus-infected monocytes induce IFN $\alpha$ from autologous HLA-DR + lymphocytes. ${ }^{9}$ We assume that the IFN $\alpha$ detected in these children was released by these mechanisms; however, other mechanisms of IFN $\alpha$ production cannot be ruled out. The finding that some patients with DHF had increasing levels of IFN $\alpha$ during convalescence may suggest that the infection was not completely eradicated even 719 days after defervescence. We did not find increasing levels of IFN $\alpha$ after defervescence in patients with $\mathrm{DF}$, which possibly indicates that the termination of virus replication is more rapidly achieved in DF.

Burke and Morrill reported that high levels of IFN $\alpha$ were detected in the plasma and cerebrospinal fluids of patients with Japanese encephalitis, and that there was a positive correlation between the levels of IFN $\alpha$ in cerebrospinal fluids and in fatal outcome. ${ }^{18}$ They interpreted that the correlation between high IFN $\alpha$ levels and fatal outcome reflects a higher degree of virus replication in the brain. Our observation that similar levels of IFN $\alpha$ were detected in patients with DHF and in patients with DF at least during the early stage of illness suggests that the degree of infection may be similar between patients with DHF and patients with DF whose symptoms are severe enough to require hospitalization. The patients with DF examined in this study were hospitalized and they had more severe symptoms than many children with DF who usually do not need to be hospitalized. Therefore, the sera of nonhospitalized children with less severe DF need to be examined in a future study.

Among patients with DHF, the levels of sIL$2 \mathrm{R}$, sCD4, IL-2, and IFN $\gamma$ were higher in subjects who had high serum levels of IFN $\alpha$ than in those who had low serum levels of IFNa, although the differences were not statistically significant for SCD4, IL-2, and IFNy. These results suggest that the levels of $\mathrm{T}$ cell activation are higher in high IFN $\alpha$ producers than in low IFN $\alpha$ producers. This difference may reflect the difference in the levels of dengue virus infections; i.e., higher levels of dengue virus replication induce higher levels of IFN $\alpha$ and also induce higher levels of $T$ cell activation.

Although this study does not suggest a direct role of IFN $\alpha$ in the pathogenesis of DHF, it is possible that IFN $\alpha$ has an important role in the 
control of dengue virus infections. Thus, the role of IFN $\alpha$ in recovery from dengue virus infection is an important subject for further investigation.

Financial support: This work was supported by grants from the U.S. Army Medical Research and Development Command (DAMA 17-86-C-6208), and from the National Institutes of Health (NIH-RO1-AI-30624 and NIH-T32-A-107272).

Disclaimer: The opinions contained herein are those of the authors and should not be construed as representing the official policies of the Department of Army or the Department of Defense.

Authors' addresses: Ichiro Kurane and Francis A. Ennis, Division of Infectious Diseases and Immunology, Department of Medicine, University of Massachusetts Medical Center, Worcester, MA 01655. Bruce L. Innis and Ananda Nisalak, Department of Virology, Armed Forces Research Institute of Medical Sciences, Bangkok 10400, Thailand. Suchitra Nimmannitya, Children's Hospital, Bangkok, 10400 Thailand. Anthony Meager, Division of Immunobiology, National Institute for Biological Standard and Control, Hertfordshire, EN6 3QG, United Kingdom.

Reprint requests: Ichiro Kurane, Division of Infectious Diseases and Immunology, Department of Medicine, University of Massachusetts Medical Center, 55 Lake Avenue North, Worcester, MA 01655.

\section{REFERENCES}

1. Halstead SB, 1980. Immunological parameters of togavirus disease syndromes. Schlesinger RW, ed. The Togaviruses: Biology, Structure, Replication. New York: Academic Press, 107-173.

2. Kurane I, Hebblewaite D, Ennis FA, 1984. Lysis of dengue virus-infected cells by natural cellmediated cytotoxicity and antibody-dependent cell-mediated cytotoxicity. $J$ Virol 52: 223-230.

3. Kurane I, Meager A, Ennis FA, 1989. Dengue virus-specific human T cell clones: serotype crossreactive proliferation, interferon gamma production, and cytotoxic activity. J Exp Med 170: 765-775.

4. Bukowski JF, Kurane I, Lai C-J, Bray M, Galbout B, Ennis FA, 1989. Dengue virus-specific crossreactive CD8+ human cytotoxic $\mathrm{T}$ lymphocytes. $J$ Virol 63: 2486-2491.

5. Kaufman BM, Summer PL, Dubois DR, Eckels KH, 1987. Monoclonal antibodies against dengue 2 virus E-glycoprotein protect mice against lethal dengue infection. Am J Trop Med Hyg 36: 427-434.

6. Kurane I, Innis BL, Nimmannitya S, Nisalak A,
Meager A, Janus J, Ennis FA, 1991. Activation of $T$ lymphocytes in dengue virus infections. High levels of soluble interleukin-2 receptor, soluble CD4, soluble CD8, interleukin 2 and interferon- $\gamma$ in sera of children with dengue. $J$ Clin Invest 88: 1473-1480.

7. Gresser I, Tovey MG, Maury C, Baudu MT, 1976. Role of interferon in the pathogenesis of virus diseases in mice as demonstrated by the use of anti-interferon serum. II. Studies with herpes simplex, Moloney sarcoma, vesicular stomatitis, Newcastle disease, and influenza viruses. JExp Med 144: 1316-1323.

8. Kurane I, Ennis FA, 1988. Production of interferon alpha by dengue virus-infected human monocytes. J Gen Virol 69: 445-449.

9. Kurane I, Ennis FA, 1987. Induction of interferon alpha from human lymphocytes by autologous, dengue virus-infected monocytes. J Exp Med 166: 999-1010.

10. Herbermann RB, Ortaldo JR, Bonnard GD, 1979. Augmentation by interferon on human natural and antibody-dependent cell-mediated cytotoxicity. Nature 277: 221-223.

11. Lindahl F, Leary P, Gressor I, 1972. Enhancement by interferon of the specific cytotoxicity of sensitized lymphocytes. Proc Natl Acad Sci USA 69: 721-725.

12. Neubauer RH, Goldstein L, Rabin H, Stebbing N, 1985. Stimulation of in vitro immunoglobulin production by interferon- $\alpha$. $J$ Immunol 134 : 299-303.

13. Technical advisory group on dengue haemorrhagic fever/dengue shock syndrome, 1986. Dengue Haemorrhagic Fever, Diagnosis, Treatment and Control. Geneva: World Health Organization.

14. Innis BL, Nisalak A, Nimmannitya $S$, Kusalerdchariya S, Chongswasdi V, Suntayakorn S, Puttisri $\mathrm{P}$, Hoke $\mathrm{CH}, 1989$. An enzyme-linked immunosorbent assay to characterize dengue infections where dengue and Japanese encephalitis co-circulate. Am J Trop Med Hyg 40:418427.

15. Meager A, Parti S, Webb K, Exley T, 1986. Development of interferon-specific monoclonal antibody for in vitro interferon assays. Dev Biol Standard 64: 237-248.

16. Meager A, Berg K, 1986. Epitope localization of a monoclonal antibody, LO-22, with broad specificity for interferon- subtypes. J Interferon Res 6: 729-736.

17. Exley T, Parti S, Barwick S, Meager A, 1984. A comparison of the neutralizing properties of monoclonal and polyclonal antibodies to human interferon alpha. J Gen Virol 126: 1120-1125.

18. Burke DS, Morrill JC, 1987. Levels of interferon in the plasma and cerebrospinal fluid of patients with acute Japanese encephalitis. J Infect Dis 155: 797-799. 